\title{
ANALYSIS OF FACTORS INFLUENCING AGRICULTURAL EXTENSION PERFORMANCE IN THE USE OF CYBER EXTENSION IN MALANG RAYA REGION
}

\author{
Sabir $^{* 1}$, Sugiyanto ${ }^{2}$, Sukesi, $\mathrm{K}^{2}$, and Yulianti, $\mathrm{Y}^{2}$ \\ ${ }^{1} \mathrm{PhD}$ Student, Doctoral Program of Agricultural Science, University of Brawijaya, Indonesia \\ ${ }^{2}$ Lecturer, Doctoral Program of Agricultural Science, University of Brawijaya, Indonesia \\ *corresponding author: sabirtato@gmail.com
}

\begin{abstract}
The potency for developing cyber extension should be utilized by agricultural extension worker in order to enrich extension material. However. It seems that the development of cyber extension was experiencing various obstacles. Based on that condition, this study aims to analyze the factors influencing the performance of cyber extension in utilizing cyber extension. The types of data used in this study were primary and secondary data. Primary data was obtained by conducting interviews with respondents. 87 respondents were determined purposively. Secondary data was obtained from documents on extension activites in Malang Raya Region. Path analysis was used in this study to answer the research objectives. Most respondents are still classified young, have a relative high education level and have a work period of less than 12 years. The result showed cyber extension socialization, personal interaction and perception of agricultural extension worker factors significantly influenced agricultural extension worker behavior. Meanwhile, factors of cyber extension socialization, perception the of agricultural extension worker and the behavior of agricultural extension worker significantly influenced the performance of agricultural extension worker in utilizing cyber extension. Only socialization and the perception of agricultural extension worker had both direct and indirect influences, where the socialization factor was the only factor with the greatest total influence value on the performance of agricultural extension worker in utilizing cyber extension. The performance of agricultural extension worker in utilizing cyber extension needed to be improved, one of which was through socialization. Socialization effort was carried out in order to increase understanding of cyber extension usefulness to agricultural extension worker. In addition, to stimulate the use of cyber extension, it was necessary to provide incentives to agricultural extension officers who utilize cyber extension.
\end{abstract}

Keywords: cyber extension, agricultural extension, path analysis

http://dx.doi.org/10.21776/ub.agrise.2019.019.2.2

Received 22 November 2018

Accepted 23 April 2019

Available online 25 May 2019

\section{INTRODUCTION}

Sustainable agricultural development requires an efficient and dynamic extension method. Indirect extension method using conventional mass media such as newspapers, leaflets, radio and television, have faced some challenges in conveying information to farmers. Printed mass media have been the main media in delivering process agricultural information which are often too late to arrive at their destination, especially in remote area and inadequate transportation facilities. Not only is the limitation of distribution, but also the number is relatively limited and expensive transporation cost. 
In the agricultural sector, information through electronic media has spread to remote villages. According to Sharma (2005), cyber extension is one of the mechanism for developing an effectively-programmed agricultural innovation in agricultural extension system. Cyber extension can improve the capacity of extension worker through timely and relevant agricultural information preparation in supporting the decision-making process for agricultural extension worker.

The support played by electronic mass media such as television and radio, sometimes the screenings are still not on time, on location and on target. Material delivery through electronic media not only requires substantial costs, but also the exposure time is limited and may not be acceptable to farmers in remote area. This approach has not been able to reach most farmers, especially in remote area. In addition, it cannot be denied that farmers' needs are far more diverse and the knowledge needed to deal with farmers' problems also vary, so agicultural extension worker demanded in various fields.

In this era, it was possible to find these solustions by using ICT to meet location-spesific information needs. With the existence of cyber extension which can be utilized by agricultural extension worker, it is expected to support the performance of agricultural extension officers, both in accessing cyber extension, utilizing information for extension extension activity and introducing cyber extension to farmers. Through cyber extension, it can increase the knowledge and skill of agricultural extension officers, because there is support to provide adequate information in order to facilitate the learning process of farmers.

The potency for developing cyber extension should be utilized by agricultural extension officers. Moreover, agricultural extension officers are currently demanded not only to be able to change behavior of farmers but also to increase food production. Therefore, agricultural extension officers were demanded to have good competency and performance. However, based on research conducting by Gatut (2008); Muliady (2009); Bahua et al (2013); Utami et al (2008); Marliati (2008) dan Hidayat (2009) revealed that most of agricultural extension officers had low competency levels. In this regard, this research aims to analyze factors affecting the performance of agricultural extension worker in utilizing cyber extension.

\section{RESEARCH METHODS}

This study is a quantitative research using survey method, where the method seeks to describe quantitatively the trends, attitudes or opinion of a particular population by examining sample of the population. This reseach was conducted in Malang Raya region. The sampling technique used in this study is purposive and snowball sampling. The type of data used in this study is primary data and secondary data. Primary data was obrained from the respondents consisting of agricultural extension officers, agricultural extension coordinator in distric level, farmer group manager and farmers in Malang Raya region. While, secondary data was obtained from documents on extension activities in Malang Raya Region.

Concurrent mixed method was used to answer the research question. Data collection techniques was conducted by observation, documentation, deep interview and Focus Group Discussion (FGD). Quantitative data were collected by using questionnaires. Those data was analyzed using descriptive statistic. 87 agricultural extension officers in Malang Raya region were selected as respondents for quantitative purposes.

Path analysis was used to find the relationship between factors influencing the performance of agricultural extension worker in utilizing cyber extension. Path analysis was used to examine the direct or indirect effect of independent variables to dependent variables. Those models was estimated using SPSS 23 software. To find which $\mathrm{X}$ variables significantly influencing $\mathrm{Y}$ variable was conducted by $\mathrm{T}$ test. Where $\mathrm{X}$ variable is significantly related to $\mathrm{Y}$ varieble if $\mathrm{p}$ value < alpha and vice versa. $\mathrm{F}$ test was conducted in order to examine the effect of $\mathrm{X}$ variables simultaneously to $\mathrm{Y}$ variable as well.

Mardikanto (2010) stated that path analysis had advantages such as:

a. The coefficient has considered the effect of other independent variables on dependent variable.

b. No autocorrelation, multicollinearity and heteroscedasticity tests are needed.

The path analysis framework in this study as follows: 


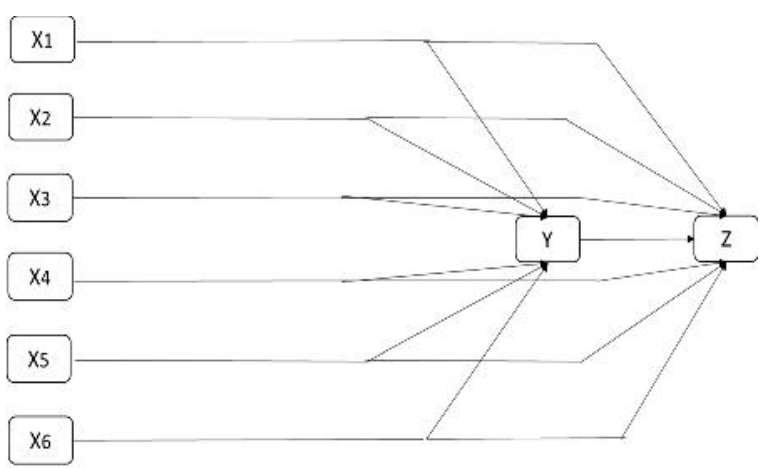

Figure 1. Factors affecting the performance of agricultural extension worker in utilizing cyber extension

Where:

1. The level of performance agricultural extension worker in utilizing cyber extension is measured based on the accessibility, the utilization and the introduction of cyber extension to farmers.

2. The performance of agricultural extension worker is influenced by individual characteristics (X1), supporting factors (X2), the quality of information (X3), cyber extension socialization (X4), personal interaction agricultural extension worker (X5) and agricultural extension worker's perception to cyber extension (X6), both influenced directly or through the behavior of agricultural extension worker about cyber extension (Y).

3. Agricultural extension worker's behavior is measured based on knowledge, attitude and skills about cyber extension.

4. kabupaten dan persepsi penyuluh terhadap cyber extension

\section{RESULTS AND DISCUSSION}

\section{Individual Characteristics}

Age, education level, and working period are factors related to the performance of agricultural extension worker. The age, education level and working period can influence the performance of agricultural extension worker. Table 1 reveals that most respondents over 51 years old are $32.18 \%$. This condition refrelcts that most agricultural extension officers in Malang Raya region were classified as old.
Table 1. The respondents characteristic of age

\begin{tabular}{ccc}
\hline Age (year) & Number & Persentase \\
\hline $25-33$ & 23 & 26.44 \\
$34-42$ & 27 & 31.03 \\
$43-51$ & 9 & 10.34 \\
$>51$ & 28 & 32.18
\end{tabular}

Source: Survey Data, 2018

In terms of education, most of respondents with undergraduate education were $79.31 \%$. There are $8.05 \%$ of total respondents who are educated at the master level. Meanwhile, respondents with DIII and SMA level of education were $6.90 \%$ and $5.75 \%$ respectively. In terms of working period, most of respondents were new employees in their institutions. Most of respondents only have working period less than 12 years which is equal to $62.07 \%$. In addition, these respondents are generally civil servant.

The high level of education was not related to increasing of motivation. It is indicated by more than $90 \%$ respondents stated that they have low motivation in using, utilizing and studying cyber extension.

This study showed that there was no respondent having high motivation in utilizing cyber extension. The study also showed that most respondents $(97.7 \%)$ had an attitude toward the use of cyber extension as an alternative choice. $2.3 \%$ of respondents had an attitude of never using cyber extsnion.

\section{Supporting Factors}

Budget allocation, policy support and infrastructure were used as 3 indicators in measuring supporting factors. In terms of goverment policy, respondents stated very supportive and supportive were $10.34 \%$ and $51.72 \%$ respectively. In terms of infratructure support aspect, respondents stated very available and available respectively were $2,30 \%$ and $49,43 \%$.

From the budget aspect, regional units that handle management of agricultural extension in Malang Raya region generally had not specifically budgeted for utilizing cyber extension. It was relected from descriptive analysis where most respondents $(86.21 \%$ ) stated that there was not budget support in order to use cyber extension. 
Those facts depicted that the attention of the local goverment in Malang Raya to the increasing of agricultural extension worker performance was not optimal. In addition, the weak political commitment and support of the local goverment toward agricultural extension resulted in low implementation, funding and inaccuracies of resource allocation.

\section{Supporting Factors}

About $47.13 \%$ and $10.34 \%$ respondents stated that there was no comformity between the agricultural extension program and the work plan of agricultural extension. On the indicator of novelty information, about $54.47 \%$ and $12.64 \%$ stated that the information was very outdated and outdated. It depicted that the information on cyber extension was less up-to-date.

In terms of easiness level of information tracking, the obtained score was 2.49 which was classified as relatively difficult category. Therefore, It makes less optimal agricultural extension officers to utilize cyber extension in order to seek the agricultural information and technolgy, convey the ideas and disseminate agricultural technology.

\section{Cyber Extension Socialization}

Based on descriptive analysis, it was obtained that cyber extension socialization activities were classified as relatively less intensive. There were $56.32 \%$ respondents who stated that they never had dialogue with cyber extension administrator. In terms of attendance of cyber extension socialization, most of respondents were never and rarely attended cyber extension socialization.

From the aspect of motivation to attend, the percentage of respondents having self-awareness to attend socialization were only $8.05 \%$, the rest was influenced by compulsion and assignment. In addition most respondents stated that very rarely involved in socialization activities. The lack of participation in socialization activites was also due to the lack of variety in media socialization.

According to agricultural extension worker appointed as cyber extension administrator in Malang Raya region, he stated that agricultural extension officers rarely attended the socialization. It was due to low motivation of agricultural extension officers. In addition, they didnt know about advantages of utilizing cyber extension.
The interaction of agricultural extension officers Factor that supports the success of cyber extension utilizing is administrator noth at the the central and regional level. The existence and activeness of administrator greatly determine the quantity and quality of an innovation and information published through cyber extension.

The result of descriptive analysis depicted that yhe existance and activeness of cyber extension administrator were classified as less active with a score of 1.86 from maximum score of 4.00. It implies that there were no active administrator in most agricultural extension center in Malang Raya region. Therefore, the communication between agricultural extension officers and administrator was also less intensive. There was no intensive information exchange among agricultural extension officers.

\section{Agricultural Extension officers' Perception}

The result of descriptive analysis depicted that the perception of agricultural extension officers regarding cyber extension were classified as not good category with a scor of 2.39 from maximum score of 4.00. Most agricultural extension officers stated that cyber extension provided benefits. Whereas they stated that the utilization of cyber extension were very comlicated and expensive. So that, respondents generally expected that cyber extension was relatively useless. This condition was in accordance with the result from Rogers and Shhoemaker (1986) who stated that the more complicated an innovation is, the more difficult to be adopted or accepted by people.

\section{The behavior of Agricultural Extension officers} Rogers dan Soemaker (1986) stated that the behavior is a real action that can be seen and observed.this behavior occurs due to the process of delivering a stimulus until there is a attitude determination to act or not act. In order to the behavior of agricutlural extension officers about cyber extension, the indicators used were knowledge, attitudes and skills of agricultural extension regarding cyber extension.

The descriptive analysis showed that the behavior of agricultural extension officers were classified as low category with a score of 2.39 from maximum score of 4.00. From knowledge aspect, it depicted that most respondents stated that they didnt know about cyber extension. From attitude 
aspect, most respondents stated that they agreed about toward cyber extension utilization. While from the aspect of skill, most respondents stated that they were less capable of utilizing cyber extension.

\section{Pengujian Hipotesis Variabel Penelitian}

Table 2 shows the result of correlation test of significant research variables. There was a negative relationship between X5 (agricultural extension officers' personal interaction) and Y (agricultural extension officers). It means that increasing the personal interaction of agricultural extension officers will reduce the level of agricultural extension behavior (knowledge, attitudes and skills) regarding cyber extension. Meanwhile, the relationship of other variable had a positive relationship.

In addition, the value of correlation cofficient between X4 and X5 were the largest value among others. In other words, the increasing cyber extension socialization to agricultural extension officers will enhance the process of exchanging messages both among extension officers and cyber extension administrators.

It can be applied to ordinal-scale variables, using the level correlation coefficient value.

Table 2 The correlation among variables

\begin{tabular}{lccccc}
\hline The variables & Corelation & p-value & The variables & Correlation & p-value \\
\hline X2 dengan X3 & 0.379 & $0.000^{* *}$ & X3 dengan Z & 0.344 & $0.001^{* *}$ \\
X2 dengan X4 & 0.480 & $0.000^{* *}$ & X4 dengan X5 & 0.537 & $0.000^{* *}$ \\
X2 dengan X5 & 0.412 & $0.000^{* *}$ & X4 dengan X6 & 0.346 & $0.001^{* *}$ \\
X2 dengan X6 & 0.219 & $0.042^{*}$ & X4 dengan Z & 0.479 & $0.000^{* *}$ \\
X2 dengan Z & 0.240 & $0.025^{*}$ & X5 dengan X6 & 0.274 & $0.010^{*}$ \\
X3 dengan X4 & 0.473 & $0.000^{* *}$ & X5 dengan Y1 & -0.248 & $0.021^{*}$ \\
X3 dengan X5 & 0.490 & $0.000^{* *}$ & X5 dengan Z & 0.440 & $0.000^{* *}$ \\
X3 dengan X6 & 0.375 & $0.000^{* *}$ & X6 dengan Z & 0.423 & $0.000^{* *}$ \\
\hline
\end{tabular}

Keterangan: correlation is significant at the 0.01 level (2-tailed) correlation is significant at the 0.05 level (2-tailed)

Estimation result of the first equation using SPSS 18 were used to analyze the influence of individual characteristics (X1), supporting factors (X2), the quality of information (X3), cyber extension socialization (X4), personal interaction of agricultural extension (X5), the agricultural extension perseption of cyber extension (X6) to agricultural extension worker behavior related to cyber extension (Y) (Table 2). The estimation of path analysis showed $\mathrm{R}$ square value were 0.359 . It implies that about $35.9 \%$ of the variation in agricultural extension worker behavior is explained by individual characteristic, supporting factors, the quality of information, personal interaction and agricultural extension officers' perception, while the rest $(64.1 \%)$ is explained by other variables. The e-value $=0.801$ shows the path coefficient of other variables outside model.

Table 3 Factors affecting agricultural extension worker behavior in utilizing cyber extension

\begin{tabular}{lcc}
\hline \multicolumn{1}{c}{ Variabel } & Standardized Coef & p-value \\
\hline Karakteristik Individu (X1) & 0.135 & 0.150 \\
Faktor Penunjang (X2) & -0.076 & 0.479 \\
Kualitas Informasi (X3) & 0.040 & 0.720 \\
Sosialisasi (X4) & 0.311 & $0.011^{* *}$ \\
Interkasi Personal (X5) & 0.202 & $0.082^{*}$ \\
Persepsi Penyuluh (X6) & 0.280 & $0.007^{* * *}$ \\
\hline R-Square & 0.359 & $0.092^{*}$ \\
F & 1.893 & \\
e $\quad 0.801$ & \\
Note: ${ }^{* * *}$ the coefficient is significant at the 0.01 level & \\
${ }^{*}$ the coefficient is significant at the 0.05 level & \\
$\quad$ the coefficient is significant at the 0.10 level &
\end{tabular}


Based on $\mathrm{F}$ test, it can be concluded that independent variables $(\mathrm{X})$ simultaneously influence dependent variable $(\mathrm{Y})$. Table 4 shows that out of the six factors considered in the model, only three variables were found to have a significant influence on agricultural extension worker behavior at the 0.05 level of significance. These variables include cyber extension socialization, personal interaction and agricultural extension officers' perception. Those variables positively influence agricultural extension officers' behavior. Meanwhile, the other variables were found to have no significant influence on agricultural extension officers' behavior.

Based on t test, there were three independent variables were found to be significant in explaining the agricultural extension officers' behavior. The three independent variables were cyber extension socialization $(\mathrm{p}=0.011<0.05)$, personal interaction $(\mathrm{p}=0.082<0.1)$ and agricultural extension officers' perception $(p=0.007<0.001)$. Those variables significantly influenced agricultural extension officers's.
In the second equation, $\mathrm{R}$ square value is 0.360 . It implies that about $36 \%$ of dependent variable (the performance of agriculturan extension officers) variation is explained by individual characteristic, supporting factors, the quality of information, personal interaction, agricultural extension officers' perception and agricultural extension officers' behavior. Meanwhile, the rest $(64 \%)$ is explained by other variables (Table 2).

The $F$ test depicted significant result, It implies that independent variables (X) simultaneously influence dependent variable $(\mathrm{Y})$. Those independent variables were individual characteristics (X1), supporting factors (X2), the quality of information (X3), cyber extension socialization (X4), the interaction of agricultural extension officers (X5), agricultural extension officers' perception (X6) and the behavior of agricultural extension officers (Y). The estimation value for e is 0.8 , it shows the path cofficient of other variables outside model.

Table 4 Factors affecting the performance of agriculture extension in using cyber extension

\begin{tabular}{|c|c|c|}
\hline Variable & Standardized Coef & p-value \\
\hline Individual characteristics (X1) & 0.136 & 0.150 \\
\hline Supported factors (X2) & -0.071 & 0.510 \\
\hline The quality of information (X3) & 0.039 & 0.729 \\
\hline Socialization (X4) & 0.315 & $0.011^{* *}$ \\
\hline Personal interaction (X5) & 0.188 & 0.125 \\
\hline Extension officer perception (X6) & 0.280 & $0.007^{* * *}$ \\
\hline Extension officer behavior (Y) & 0.037 & $0.071^{*}$ \\
\hline R-Square & 0.360 & \\
\hline $\mathrm{F}$ & 7.474 & $0.000^{* * * *}$ \\
\hline $\mathrm{e}$ & 0.800 & \\
\hline
\end{tabular}

Based on $t$ test, only three independent variables were found to be significant in explaining the performance of agricultural extension officers. The three independent variables were cyber extension socialization $(\mathrm{t}=2.619, \mathrm{p}=0.011)$, agricultural extension officers' perception on cyber extension $(\mathrm{t}=2.773, \mathrm{p}=0.007)$ and agricultural extension officers' behavior $(\mathrm{t}=2.385, \mathrm{p}=0.071)$. Three variables significantly influenced the performance of agricultural extension officers.
The estimation of the model coefficient for $\mathrm{b}_{0}$ is $-0.177, \mathrm{X}_{1}$ is $0.153, \mathrm{X}_{2}$ is $-0.42, \mathrm{X}_{3}$ is $0.033, \mathrm{X}_{4}$ is $0.276, \mathrm{X}_{5}$ is $0.199, \mathrm{X}_{6}$ is 0.312 and $\mathrm{Y}$ is 0.034 . Therefore, the estimated in equation 2 is as below:

$$
\begin{aligned}
Z= & -0.177+0.153\left(X_{1}\right)-0.42\left(X_{2}\right)+0.033\left(X_{3}\right)+ \\
& 0.276\left(X_{4}\right)+0.199\left(X_{5}\right)+0.312\left(X_{6}\right)+0.034 \\
& (Y)
\end{aligned}
$$


Beta coefficient or standardized regression coefficient was utilized to compare the strengh of this coefficient to the coefficient for another variable. As depicted in Table 4, the largest Beta coefficient is 0.315 which is for cyber extension socialization. The Beta value for personal interaction 0.280 is the second highest and the Beta value for agricutlrual extension behaviors' 0.037 is the smallest.

Furthermore, those equation depicted total effect on each variable. Where total effect is the sum of the direct effect of a variable $\mathrm{X}$ on $\mathrm{Z}$ and indirect effect of variable on $\mathrm{Z}$ through $\mathrm{Y}$ variable.

Total direct effect of socialization variable is equal to 0.327 . The indirect effect of $\mathrm{X} 4$ variable on $\mathrm{Z}$ is obtained by multiplying beta $\mathrm{X} 4$ on $\mathrm{Y}$ with beta $\mathrm{Y}$ on $\mathrm{Z}$ which is equal to $0.037 \times 0.311=$ 0.012 . Therefore, the total effect of socialization variable on the performance of agricultural extension officers is 0.327 .

The total effect of agricultural extension officers' perception variable is the sum of direct effect of X6 variable on $\mathrm{Z}$ variable and indirect effect of $\mathrm{X} 6$ variable on $\mathrm{Z}$ through $\mathrm{Y}$ variable. The direct effect of $\mathrm{X} 6$ variable on $\mathrm{Z}$ variable is 0.280 . The indirect effect of $\mathrm{X} 6$ variable on $\mathrm{Z}$ variable was obtained by multiplying beta of X6 with beta of $\mathrm{Y}$ which is $0.037 \times 0.304=0.011$. Therefore, the total effect of $\mathrm{X} 6$ on $\mathrm{Z}$ is 0.291 .

This study depicted that individual characteristics didnt significantly influence both the behavior and the performance of agricultural extension officers. These results were similar to research conducted by Anwas (2009); Helmy (2013). It was expected to be caused by the absence of motivation from within agricultural extension officers in understanding cyber extension.

Marius et al (2007); Nuryanto (2008) and Mulyadi (2009) stated that the low motivation of agricultural extension officers was due to lack of competency of agricultural extension officers. It was supported by Slamet (2008), where agricultural extension officers tended to be unprofessional and relatively incapable of adapting to the situation.

This study also showed that the performance of agricultural extension officers were not signiciantly influenced by supporting factors. It was due to similarity of infrastructure, policy and budgeting among agricultural extension center, where those supporting factors were not in line with the agricultural extension worker expectation.
Agricultural extension officers generally complained that there was no incentive to access cyber extension. It was in accordance with the study conducted by Sumardjo et al (2009), where the limitation of infrastructure, managerial and human resource capacity cause cyber extension utilization nonoptimal.

The performance of agricultural extension officers in utilizing cyber extension were also not significantly influenced by the quality of information. They assumed that cyber extension were rarely uptodate. Moreover, they tend to prefer searching any informations as material extension on google instead of cyber extension.

Positive sign of $\mathrm{X} 4$ variable showed a direct relationship between cyber extension socialization and the performance of agricultural extension officers. It also implied that an increase in efforts to communicate to agricultural extension officers regarding cyber extension will increase the performance of agricultural extension officers.

Interaction personal variable also showed a positive sign. It implied that an increase in intensity of exchanging messages between agricultural extension and cyber extension administrator will improvethe performance of agricultural extension officers in utilizing cyber extension. The result were similar to the resultof Anggoroseto (2012) who states that the interaction between agricultural extension officers and administrator significantly influence the performance of agricultural extension officers in utilizing cyber extension.

Similar to X4 and X5 variables, X6 variable showed a positive sign which means that inrease the perseption of agricultural extension officers on cyber extension will also increase the performance of agricultural extenion workers in utilizing cyber extension. According to Amin (2014), information obtained through cyber extension was easy to apply in farming activities, because most information needed by farmers was available on cyber extension. Positive perseption indicates that agricultural extension officers perceived a new technological innovation (cyber extension) as meaningful and beneficial for themselves. This was consistent with the definition of a person's perception, where the perseption was interpreted as individual stimulus of what he is sensing (Walgito 2006). 


\section{Policy Implication}

Based on the estimation result, cyber extension socialization variable was the most dominant variable among other variables. Unfortunately, descriptive analysis revealed that socialization activity was classified as less intensive. It was generally caused by internal side of agricultural extension workers. In addition, the analysis showed that most agricultural extension workers were less involved in various socialization activities.

The wrong perception of agricultural extension workers was expected as the main factor influencing why most agricultural extension workers did not take part in socialization. Agriculurtural extension workers assumed that the utilization of cyber extension was relatively useful but complicated and costly. Anggoroseto (2012) stated that agricultural extension workers tend to have bad perception of cyber extension. They viewed that cyber extension only provided the obsolate techincal knowledge, where thay had already known. In addition, agricultural extension workers also assumed that cyber extension utilization needed special knowledge and expensive cost.

In addition, agricutlural extension workers tend to look for extension material using google. This condition is cotrary to the advice of extension material based on UU No. 16 of 2006 concerning extension system which stated that the material conveyed to the main actors and business actors must obtain recommendations from goverment institution, except for technology sourced from traditional knowledge.

To shift the view of agricultural extension workers requires various efforts, one of which is cyber extension socialization. Cyber extension socialization are used in order to increase understanding of usefulness of cyber extension to agricultural extension workers. In addition, socialization will increase the understanding of agricultural extension workers to cyber extension which will further improve the performance of agricultural extension workers.

\section{CONCLUSION}

Agricultural extension workers in Malang Raya Region were characterized by the mojority of young agricultural extension workers (25-51 years), undergraduate education level (79.31\%) and with a period of less than 12 years. However, the high level of education was not in line with the increasing of motivation. More than $90 \%$ respondents stated that they had low motivation in utilizing, studying and utilizing cyber extension. In addition, more than $97 \%$ respondents assumed that cyber extension only was the alternative choice in seeking extension material.

Therefore, the intention of developing cyber extension seemed to be facing carious challenges. The chalengges come from the internal factors of agricultural extension workers themselves. It was depicted in the low of agricultural extension workers' behavior (knowledge, attitudes and skills) regarding cyber extension. It caused the performance of agricultural extension worker low. Apart from the internal factors of agricultural extension workers, extrnal factors such as supporting factors, the quality of information, socialization, personal interaction and the perception of agricultural extension workers regarding cyber extension were also categorized as low level.

Based on the result of path analysis estimation, it was found that only socialization and agricultural extension workers' perception regarding cyber extension significantly influenced the performance of agricultural extension workers in utilizing cyber extension. Both cyber extension socialization and the perception of agriculutral extension workers had positive influence on the performance of agricultural extension workers in utilizing cyber extension. In other words, an increase in these two factors will improve the performance of agricultural extension workers in utilizing cyber extension. The estimation result also depicted that cyber extension socialization factor had a greater influence amont other factors.

\section{SUGGESTION}

The performance of agricultural extension workers in utilizing cyber extension needed to be improved, one of which was through socialization. Socialization was used in order to increase the understanding of cyber extension usefulness to agricultural extension workers. Therefore, it was ude in order to provide awarness to agricultural extension workers on the importance of cyber extension utilization.

In addition,the goverment needed to provide computer equipment facilities at each agricultural extension center. It was utilized in order to increase 
the availability facilities for supporting the improvement of the performance of agricultural extension workers in utilizing cyber extension. In addition, to stimulate cyber extension utilization was necessary to provide incentives for agricultural extension workers who utilize cyber extension. The incentives can be in the form of fees to agricultural extension workers who upload their extension material on cyber extension. It was expected that the level of agricultural extension workers' performance in utilizing cyber extension can increase

\section{REFERENCES}

Amin, M, 2014. Efektivitas dan Perilaku Petani dalam Memanfaatkan Teknologi Informasi Berbasis Cyber Extension. Informatika Pertanian, 23(2): 211-219.

Anggoroseto, P. 2012. Faktor-Faktor yang Mempengaruhi Kinerja Penyuluh dalam Pemanfaatan Cyber Extension di Kabupaten Bogor. [Tesis]. Surakarta (ID): UNS.

Anwas, E.O.M., Sumardjo, Asngari, P.S., dan Tjitropranoto, P. 2009. Faktor-Faktor yang Mempengaruhi Penyuluh dalam Pemanfaatan Media. Jurnal Komunikasi Pembangunan, 7(2): 68-81.

Bahua, M.I., Jahi, A., Asngari, P.S., Saleh, A., \& Purnaba IGP. 2013. Factors affecting the performance agricultural extension and their impact at behavior maize farmers in Gorontalo Province. Journal Education and Extension, 1:1-10.

Gatut, B.N. 2008. Kompetensi Penyuluh Sarjana dalam Pembangunan Pertanian: Kasus di Provinsi Jawa Barat. [Disertasi]. Bogor (ID): Institut Pertanian Bogor.

Hidayat, S.I. 2009. Analisis kinerja penyuluh pertanian di wilayah kerja unit penyuluhan pertanian Sukodono, Sidoarjo. Jurnal Habitat, 20(1): 45-56
Mardikanto, T. 2010. Metode Penelitian dan Evaluasi Pemberdayaan Masyarakat. UNS Press: Surakarta.

Marliati, Sumardjo, Asngari P.S., Tjitropranoto P., \& Saefuddin, A. 2008. Faktor-Faktor Penentu peningkatan kinerja penyuluh pertanian dalam memberdayakan petani (Kasus di Kabupaten Kampar Provinsi Riau). Jurnal Penyuluhan, 4(2): 92-99.

Muliady, T.R., 2009. Faktor-faktor yang mempengaruhi kinerja penyuluh pertanian dan dampaknya pada perilaku petani padi di Jawa Barat. [disertasi]. Bogor (ID) : Institut Pertanian Bogor.

Marius, J.A., Sumardjo, Margono Slamet, Pang S.Asngari. 2007. "Pengaruh Faktor Internal dan Eksternal Penyuluh terhadap Kompetensi Penyuluh di Provinsi Nusa Tenggara Barat."Jurnal Penyuluhan, Vol 3 No 2. September 2007, hal 78-89.

Sharma, V.P. 2005. Cyber Extension: Leveraging the Inforevolution to Improve Rural Livelihoods Case Studies in Agricultural Extension .

Slamet, Margono. 2008. Menuju Pembangunan Berkelanjutan melalui Implementasi UU No. 16 tahun 2006 tentang Sistem Penyuluhan Pertanian, Perikanan, dan Kehutanan. Dalam Pemberdayaan Manusia Pembangunan yang Bermartabat. Penyunting: Adjat Sudrajat dan Ida Yustina. Bogor: Pustaka Bangsa Press.

Sumardjo, Baga, L.M., and Mulyandari, S.H. 2009. Kajian Cyber Extension (laporan Kegiatan). Departemen Pertanian.

Utami, B.W., Widiyanti, E., \& Wibowo, A. 2008. Kinerja Penyuluh Pertanian Lapang (PPL) dalam pengembangan beras organic menuju terwujudnya Kabupaten Sragen sebagai sentra beras organic. Jurnal Agritexts, 24: 1-12.

Walgito, B. 2006. Pengantar Psikologi Umum. Yogyakarta: Andi offset. 